\title{
Identification, Phenology, Ecological Habitat and Damage Caused by Loranthaceae in Plantations of Rural Area of Daloa, Côte d'Ivoire
}

\author{
AMON Anoh Denis-Esdras ${ }^{1, *}$, YAO Kouadio Maurisonne, KOUAKOU \\ Kouassi Jean-Luc, SORO Dodiomon ${ }^{2}$
}

\footnotetext{
${ }^{1}$ Agroforestry Training and Research Unit, Jean Lorougnon Guédé University

${ }^{2}$ Botanical Laboratory, Biosciences Training and Research Unit, Félix Houphouët-Boigny University. 22 PO Box, 582 Abidjan 22, Côte d'Ivoire.

*Corresponding author
}

\begin{abstract}
Loranthaceae are parasitic vascular plants that live and thrive at the expense of other woody plants. They proliferate on various woody plants and pose a threat to the host. It seemed important to know the pest species implicated in plantations. The target of this study is to identify Loranthaceae in plantations in periurban areas of Daloa to determine their phenology, to know their ecological habitat and to identify the damage caused to hosts, in order to raise the alarm bell the destructive impact of this plant biodiversity on other woody plants. Surveys and botanical inventory carried out on 25 plantations made it possible to identify three species divided into two (2) genera of which the most distributed on all the plantations prospected was Tapinanthus bangwensis (100\% presence). The results of the phenophase observations of the three species showed that they overlap in duration and are not independent of each other. Five major damage was observed. Complete defoliating of host branches (45\%) and drying of parasitized branches $(32.7 \%)$ were the predominant damage observed. Knowledge of the phenology of these parasitic species could be used to develop strategies for the effective control of their spreading at favorable times.
\end{abstract}

Keywords - Periurban plantations, Loranthaceae, phenophase, damage, targeted control.

\section{INTRODUCTION}

Loranthaceae are hemiparasitic vascular plants that live at the expense of other woody plants cultivated or not. Sometimes unrecognized, this plant biodiversity is in recent decades an agronomic problem in some plantations in sub-saharan Africa (Salle, 2004). Today, due to poor climatic conditions resulting from excessive deforestation, these parasitic plants have found favored hosts in other woody species (Amon, 2014). In Côte d'Ivoire, by traversing fields and plantations in the countryside, they invade in large numbers the plant of crops and other associated woody plants (Soro, 2010). The main question is how to eradicate them. But, how to eradicate them within plantations without a better prior knowledge of the parasite species involved and their biology? In Côte d'Ivoire, studies on this plant biodiversity have been carried out by several authors (Traoré et al., 2003, Soro, 2006, Soro,
2010), however, many aspects relating to their distribution and their biology remain deepen to better fight (Salle and Aber, 1986). In the Daloa plantations, where no specific Loranthaceae study has yet been carried out, it seemed important to better understand these phytoparasites. In order to do this, the overall target of this study is to inventory, identify the species of Loranthaceae in plantations in the periurban areas of Daloa and determine their phenology. Specifically, this will involve: (1) identifying Loranthaceae species and determining their vegetative phases; (2) know their ecological habitat and their position on the host; (3) to identify the possible damage caused to the hosts and to specify the means of struggle used by the by peasants. 


\section{MATERIAL AND METHODS}

\subsection{Study area}

The study was carried out in plantations in the periurban areas of Daloa, a Department of the Haut-Sassandra region, in west-central Côte d'Ivoire, with geographical coordinates of $6^{\circ} 53 \mathrm{~N}$ Latitude and $6^{\circ} 27 \mathrm{~N}$ Longitude. The climate of the study area is of the equatorial type of transition with two rainy seasons (from march to july and from september to november) which alternate with two dry seasons (from december to february and in august). The average annual rainfall is $1500 \mathrm{~mm}$ and an average annual temperature of $26^{\circ} \mathrm{C}$. Its vegetation consists of forest islands and farms.

\subsection{Equipment}

Plant material is composed of woody species from plantations and Loranthaceae. The technical material includes a geographic positioning device (GPS), a digital camera, a pair of binoculars, a survey sheet and a plastic cover.

\subsection{Methods}

Surveys were carried out in 25 plantations in periurban areas of Daloa aged 15 to 35 years. These plantations were chosen at random and visited after exchange with the peasants who owned the fields. It consisted of recording, using a leaflet in each plantation visited, the name of the parasite species encountered, the number of clumps per parasite, their different phenophases (flowering, fruiting and vegetative growth), their ecological habitat, position on host and damage to parasitized plants. In the plantations, direct observations were made two to three times per month from may 2017 to april 2018, using an experimental system consisting of plastic cover placed underneath some clumps of randomly listed parasitic species (Amon, 2014). In total, two (2) devices per parasite species and by plantations were laid. This process allowed to collect and to determine from the fall or not of the flowers and the fruits of the clumps of the data, the phenological stages of each species of Loranthaceae met in the plantations prospected.

\section{RESULTS AND DISCUSSION}

\subsection{RESULTS}

\subsubsection{Inventory of Loranthaceae species from peri- urban plantations in Daloa}

Three (3) species of Loranthaceae were identified on all the plantations surveyed. They are Phragmanthera capitata (Spreng.) Ballé (Fig. 2), a species recognizable by its opposite or sub-opposite leaves with a petiole, shaggy at first, then glabrous, is canaliculate. The inflorescence is an axillary umbel of 3 to 4 flowers. The corolla $3.5 \mathrm{~cm}$ long at $6.5 \mathrm{~cm}$ is yellow with a reddish tip. Tapinanthus bangwensis (Engl. And K. Krause) Dancing (Fig. 3), a shrub with twigs up to $75 \mathrm{~cm}$ long. This plant has leaves are simple whole or wavy, oval elliptical, glabrous and shortly petiolate, sub-opposite or whorled. The inflorescence is an umbel. The corolla is red, streaked, darker towards the summit. The fruits are berries of red color when ripe. With regard to $T$. sessilifolius (P. Beauv.) Van Tiegh. (Fig. 4) is an entirely hairless plant with branches up to $40 \mathrm{~cm}$ long. Its leaves are opposite and subopposite, sessile or subsessile. It has 4 to 8 reddish flowers, grouped into axillary umbels, solitary then fasciculate.

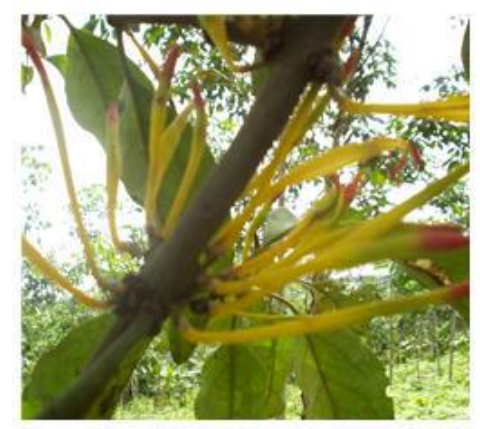

Fig. 2: Flowering branch of Phragmanthera capitata

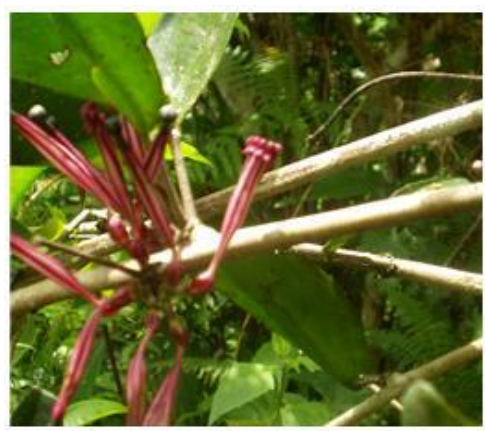

Fig. 3: Flowering twig of Tapinanthus bangwensis

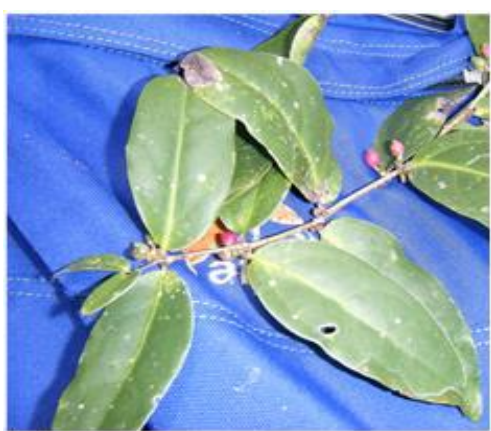

Fig. 4: Fruiting branches of T. sessifilolius 


\subsubsection{Phenology of Loranthaceae species encountered}

The phenological stages (vegetative

growth, flowering and fruiting) of Loranthaceae species identified in the prospected plantations are observed and determined (Table 1). The phenophases of the three parasite species observed are not independent of each other. They overlap during the year in the plantations visited. Tapinanthus bangwensis begins its fruiting phase from mid-november to mid-February in periurban plantations. It marks a 2nd phase of fruiting between may and mid-June. Regarding the vegetative growth phase of this species, it occurs between mid-february and march, and from mid-June to mid-august. Its flowering phase is observed in april, then from mid-august to mid-november. At Tapinanthus sessilifolius, the fruiting phase takes place between december and february, and from June to mid-July in periurban plantations surveyed. Then from mid-August to mid-november. At Tapinanthus sessilifolius, the fruiting phase takes place between december and february, and from June to mid-july in periurban plantations surveyed.
The vegetative growth phase of this plant is observed from mid-July to August, then in march. It performs its flowering phase between september and november, and from april to may. As for Phragmanthera capitata, its fructification phases are only observed between midnovember and february, then in may. It begins its vegetative growth phase between june and august and ends in march. The flowering phase this plant usually takes place between september to mid-november, then in april in the suburban plantations visited.

\subsubsection{Distribution and ecological habitat of pests in plantations}

Figure 5 shows that the three species of Loranthaceae inventoried are variously distributed over all plantations periurban areas prospected. Tapinanthus bangwensis is observed in 25 prospected periurban plantations, either $100 \%$ presence. This species recorded the highest average number of tufts $(11,404$ tufts) on the host $76,14 \%$ of the total tufts.

Table 1. Phenological stages of Loranthaceae species identified in plantations

\begin{tabular}{|c|c|c|c|c|c|c|c|c|c|c|c|c|}
\hline \multirow[b]{2}{*}{ Parasitic species } & \multicolumn{12}{|c|}{ Month } \\
\hline & $\mathrm{J}$ & $\mathrm{F}$ & Ms & $\mathrm{A}$ & $\mathrm{Mi}$ & $\mathrm{Jn}$ & $\mathrm{Jt}$ & At & $\mathrm{S}$ & $\mathrm{O}$ & $\mathrm{N}$ & $\mathrm{D}$ \\
\hline \multicolumn{13}{|l|}{ Tapinanthus bangwensis } \\
\hline \multicolumn{13}{|l|}{ Tapinanthus sessilifolius } \\
\hline Phragmanthera capitata & & & & & & & & & & & & \\
\hline
\end{tabular}

Vegetative growth
Flowering

\section{Fructification}

It is heliophilus and usually attaches around the crown of its hosts (Table 2). As for Phragmantera capitata, it is only found in 11 of the 25 plantations surveyed (44\%). It is moderately distributed $(2,468$ tufts $)$, or $16.48 \%$ of the total recorded tufts, unlike $T$. sessilifolius (1,106 tufts), which is very poorly distributed over all the plantations surveyed (Fig. 5). This parasitic plant is observed only in 7 plantations (28\%). Phragmantera capitata is present in several humid and ventilated locations of the prospected plantations. This species is helio- sciaphile unlike $T$. sessilifolius which is heliophilus and inhabits aerated media (Table 2).

Indeed, it is fixed both outside and inside the crown of its guests encountered.

\subsubsection{Damage to guests in plantations in periurban areas of Daloa}

In this study, a number of Loranthaceae related damages were observed on woody host plants in the periurban areas of Daloa. Five major damage was observed. These are: totally invading the hosts by the

parasites $(12.3 \%)$ Fig. 6A, the defoliation or complete defoliation of branches of the host subjects $(45 \mathrm{~b} \%)$, the desiccation of the parasitized branches (32.7\%) Fig. 6B, bulge formation at the point of insertion of the parasite, often with gaping cavities sometimes serving as ants ant (9\%) Fig. 6C,

and death of the infested subject (1\%), Fig. 6D. Of all the damage recorded, the complete defoliating of twigs of parasitized individuals and the drying up of the parasitized branches were the most commonly observed damages on all plantations in periurban areas surveyed. 
International Journal of Environment, Agriculture and Biotechnology, 5(5)

Sep-Oct, 2020 / Available: https://ijeab.com/

\subsubsection{Fight against Loranthaceae}

The control method (25\% of responses) used against the Loranthaceae by farmers encountered on plantations is still traditional and not very constant. Indeed, some of them admit to practice a few times the method of mechanical control (9\% of responses).

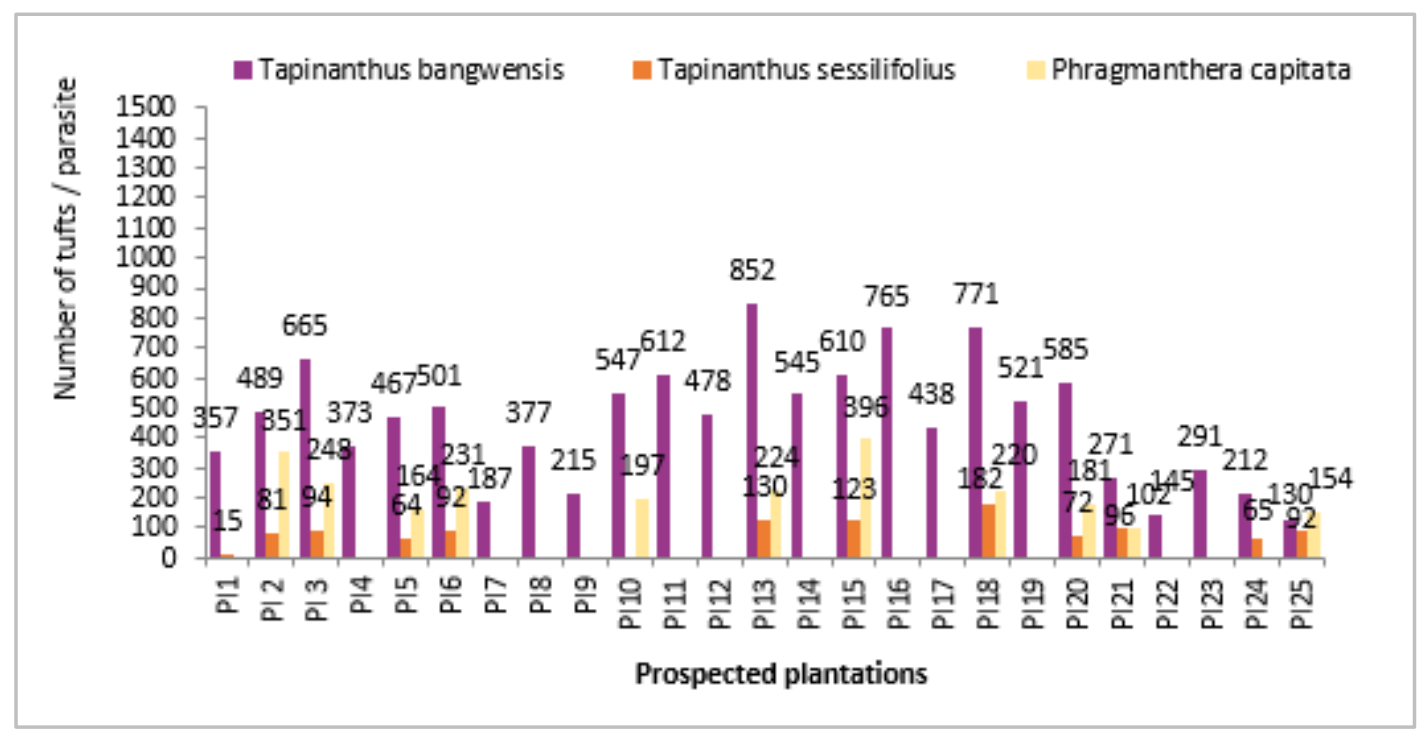

Fig. 5. Distribution of Loranthaceae species in prospected periurban plantations
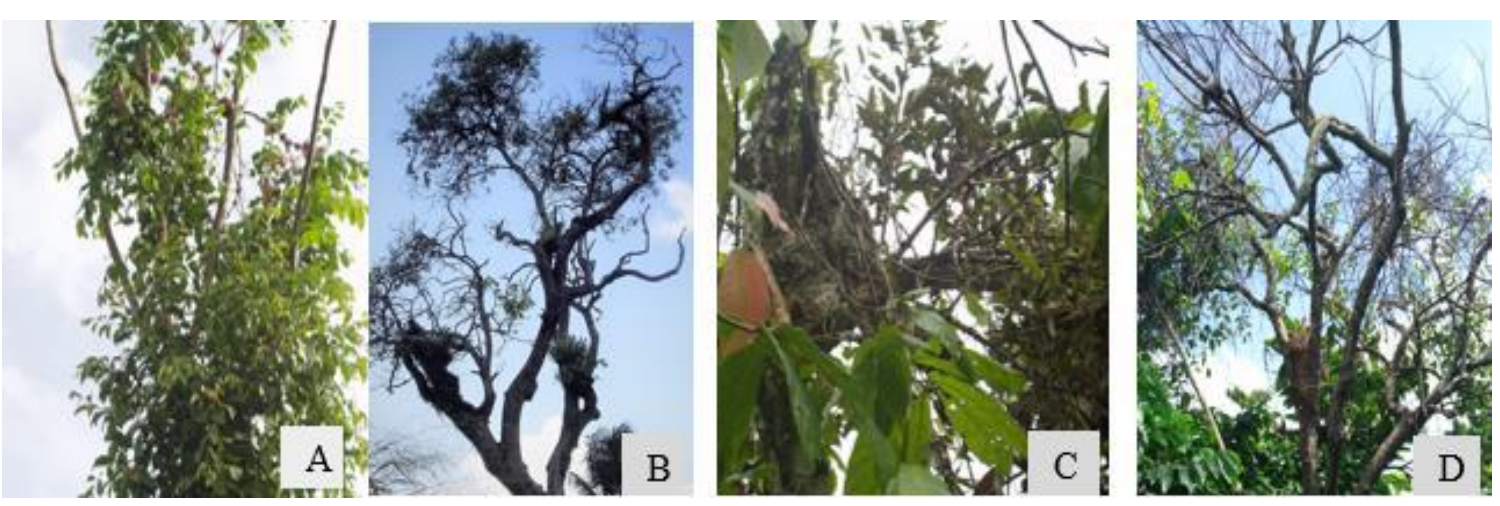

Fig. 6. Loranthaceae attack damage: total invasion (A), dehydration of infested branches $(B)$, formation of anthill $(C)$ and death of a host subject $(D)$

Table 2. Habitat and ecological position of Loranthaceae species encountered

\begin{tabular}{|c|c|}
\hline Parasitic species & Characteristics \\
\hline Phragmanthera capitata & $\begin{array}{c}\text { Present in many wet and aerated places (Helio-sciaphile), lives both } \\
\text { outside and inside the crown of the host. }\end{array}$ \\
\hline Tapinanthus bangwensis & $\begin{array}{l}\text { Heliophilus, present in many stations, lives especially around the } \\
\text { crown of its hosts }\end{array}$ \\
\hline T. sessilifolius & $\begin{array}{l}\text { Heliophilus, inhabits aerated biotopes and usually develops from the } \\
\text { crown of parasitized subjects. }\end{array}$ \\
\hline
\end{tabular}




\subsection{DISCUSSION}

\subsubsection{Phenology of Loranthaceae species}

Observations of the phenology of the different species of Loranthaceae made show dependence on each other. They overlap and vary little from one species to another. Concurrently, flowers and fruits of different stages of growth are found in the clumps of the Loranthaceae. This situation, which is not new, has already been reported

by Soro (2010). According to Boussim et al.

(1993b), only late, early or prolonged flowering of parasite species during the year could explain this condition. Also, for these authors, the knowledge of the vegetative phases of parasitic plants better explains the abundance and distribution of this plant biodiversity in all the tropical zones of Africa.

\subsubsection{Distribution of Loranthaceae species in plantations}

The botanical inventory of parasitic plants made it possible to inventory three species of Loranthaceae in plantations in peri-urban areas of Daloa. Tapinanthus bangwensis is abundant and more distributed with $100 \%$ presence in the plantations surveyed. It is followed by Phragmanthera capitata (44\% presence). These results reflect the health profile of plantations in the periurban areas of Daloa strongly dominated by Tapinanthus bangwensis and Phragmanthera capitata. In Côte d'Ivoire, there are no woody species that are not parasitized by this species (Amon, 2006). Traoré and Da (1996), Soro et al. (2004b) Soro (2006) revealed a predominance of Tapinanthus bangwensis in Shea and Nere plantations in the north of the country. In other African countries, Boussim et al. (1993b) in Burkina Faso and Ahamide et al. (2015) in Benin report a predominance of the species Tapinanthus bangwensis respectively on shea and colatier. The predominance of this plant in periurban plantations is worrying, given the enormous damage that the genus Tapinanthus causes to shea in Africa (Boussim et al., 1993b). Indeed, according to Salle (2004), the damage of the genus Tapinanthus on trees in the Sahelian zone, would have a more destructive impact than the famous desert locusts, because it can even lead to the death of the parasitized subjects.

\subsubsection{Damage to guests encountered}

Several damages such as completely invade the host, the defoliation or complete defoliation of branches, the drying of the branches, formations of beads at the point of insertion of the parasite, presence of gaping cavities in the beads serving as anthills and death of the Infested subject are observed in plantations in Daloa during the study. The same damage, the complete defoliating of branches, the drying out of the branches, damages very often cause the slowing down of parasitized plants and in the long term, the death of certain parasitized plants (Houenon et al., 2012). Deformations or bulge formations at the point of attachment of the parasite on the host were observed. These observations are confirmed by Aké-Assi (1984) who reported that these disturbances are the consequence of the host's reaction to the penetration of the haustorium of the parasite into the tissues.

\section{CONCLUSION}

Periurban plantations are parasitized by two parasitic species of the family Loranthaceae. The presence of these two species in all the plantations surveyed of the study sites constitutes a threat to consider considering the damage they cause on the infested subjects. Also, the present study could bring real information on the phenology of each identified pest species, as well as the damage due to their attacks. Knowledge of the phenological stages of plant pests may allow the development of a targeted and effective control program at appropriate times.

\section{ACKNOWLEDGEMENTS}

The peasants anonymous met in this study for their collaboration

\section{REFERENCES}

[1] Innocent, D.Y., Ahamide, Monique, G., Tossou, Aristide, C., Adomou. Janvier, G., Houenon, Hounnankpon Yedomonhan et Akpovi Akoegninou, (2015). Diversité, impact et usage des Loranthaceae parasites de Cola nitida (Vent.) Schott. \& Endl. $\mathrm{Au}$ Sud-Benin.International Journal of Biological and Chemical Sciences. 9 (6): 2859-2870

[2] Aké-Assi, L. (1984). Flore de Côte d'Ivoire: Étude descriptive et biogéographique avec quelques notes ethnobotaniques. Thèse de Doctorat, Université d'Abidjan, 1206p.

[3] Amon, ADE. (2006). Les plantes vasculaires parasites de la famille des Loranthaceae rencontrées dans le département de Grand-Bassam, au Sud de la Côte d'Ivoire. Mémoire de D.E.A. de Botanique, Université de Cocody, U.F.R. Biosciences Abidjan, Côte d'Ivoire, 57p.

[4] Amon, A.D.E. (2014). Les Loranthaceae (guis), hémiparasites vasculaires des arbres et des arbustes des agroécosystèmes de la région du Sud-Comoé, en zone de forêt dense sempervirente de la Côte d'Ivoire. Mémoire de Thèse de l'Université Félix Houphouët-Boigny, option Agroforesterie : 213p.

[5] Boussim, I.J., Sallé G., et Guinkio, S. (1993b). Tapinanthus du karité au Burkina Faso, $2^{\text {ème }}$ partie: Phénologie, biologie et dégâts. Bois et Forêt des Tropiques, 238: 53-65. 
[6] Houenon (1998). Premier rapport sur la connaissance des Loranthaceae en République du Bénin. Identification, distribution et dégâts, Cotonou. Document de IITA Benin, 13 p.

[7] Houenon, G.J, Yedomonhan, H., Adomou A.C., Tossou G.M., Akoegninou A., et Traoré (2012). Diversité Spécifique des Loranthaceae Parasites des Agrumes et Leurs Impacts Sur la Production Agrumicole au Sud du Bénin. European Journal of Scientific Research: 527-538.

[8] Salle, G., et Aber M. (1986). Les phanérogames parasites: biologie et stratégies de lutte. Revue de Cytologie et Biologie Végétales. France, Lettre botanique 3: 235-263.

[9] Salle, G. (2004). Les plantes parasites, 14p. http://www.futurasciences.com/magazines/botanique plantes parasites [Consulté le 4/11/2019]

[10] Soro, D., N'Da, Soro D., Ouattara D., P.K., Da et D., Traoré (2004b). Efficacité de l'émondage contre les Loranthaceae ou guis du karité : cas du parc naturel à karité de Tengrela dans le Nord de la Côte d'Ivoire. Annales de Botanique de l'Afrique de l'Ouest 3 : 87-95

[11] Soro D. (2006). Le karité, Vitellaria paradoxa Gaertn. f. (Sapotaceae). Variabilité de quelques caractères morphologiques, production en fruits et moyen de lutte par émondage contre les Loranthaceae parasites. Le cas du parc naturel à karité de Tengrela, Nord de la Côte d'Ivoire. Mém. de thèse, UFR Biosciences, Université de Cocody (Côte d'Ivoire), 142p.

[12] Soro, K. (2010). Les Loranthaceae (guis) des agroécosystèmes dans l'Ouest de la Côte d'Ivoire: flore, parasitisme et usages dans les Départements de Oumé, de Gagnoa et de Soubré. Mémoire de Thèse de l'Université de Cocody-Abidjan, option Agroforesterie : $183 \mathrm{p}$.

[13] Traoré, D., et Da K. (1996). Lutte contre les plantes vasculaires parasites du karité et du néré dans le Nord de la Côte d'Ivoire. Cas des Départements de Korhogo, Boundiali, Ferkessédougou et Tengréla. Rapport annuel de PEP/A.I.S.A.CI., 97p.

[14] Traoré D., Da K.P. et Soro D. (2003). Lutte contre les plantes vasculaires parasites du karité, dans le Nord de la Côte d'Ivoire. Cas du parc naturel à karités de Tengrela, Universités de Cocody, U.F.R. Biosciences, Laboratoire de Botanique Rapport de P.E .P/A.I.S.A. CI., 116p. 